\title{
Global Perceptions of Faculties on Virtual Programme Delivery and Assessment in Higher Education Institutions During the 2020 COVID-19 Pandemic
}

\author{
Oluwasola Babatunde Sasere $^{1} \&$ Sekitla Daniel Makhasane ${ }^{1}$ \\ ${ }^{1}$ University of the Free State, Faculty of Education, School of Education Studies, Qwaqwa Campus, Private Bag X13, \\ Phuthaditjhaba, Republic of South Africa \\ Correspondence: Oluwasola Babatunde Sasere, University of the Free State, Faculty of Education, School of \\ Education Studies, Qwaqwa Campus, Private Bag X13, Phuthaditjhaba, Republic of South Africa.
}

Received: June 132020

Accepted: July 20, 2020

Online Published: July 21, 2020

doi:10.5430/ijhe.v9n5p181

URL: https://doi.org/10.5430/ijhe.v9n5p181

\begin{abstract}
Amidst the outbreak of COVID-19 worldwide, virtually all national governments declared a "lockdown" of all institutions in a bid to curtail its spread. This posed serious challenges to programme delivery and assessment in Higher Education Institutions (HEIs), with foreseeable long and short-term consequences. This study investigated the effectiveness of virtual programme delivery and assessment in Higher Education Institutions (HEIs) during the COVID-19 (Corona Virus) pandemic, from a global perspective. The study assesses the success rate of virtual teaching and learning via various online platforms that were set up to make up for time lost due to the unanticipated global HEIs closure. Organisational Change Theory was used to inform the study, within the confines of simple qualitative research approach. Data were collected using interview while participants were selected through convenience sampling technique via online platforms such as the reputable online academic community, email, WhatsApp, and the UNESCO website. Data were analysed using thematic analysis. The findings revealed disparities in responses to virtual learning across HEIs and national contexts. Training and re-training of lecturers and students, and the provision of virtual learning enabling infrastructure, were recommended to mitigate similar situation in future.
\end{abstract}

Keywords: virtual Learning, programme delivery and assessment, COVID-19, HEIs

\section{Introduction}

There is a systemic relationship between 'institutions' and 'society', and a 'Higher institution' is a subset of a system called the 'society' (Francois 2015; Gary et al, 2013). Research and graduate dynamics within the Higher Education Institutions (HEIs) culminate in societal development, while changes in the dynamics of the environment/society also determine the operations of HEIs (Adedayo, 2015 and Mark, \& Sar, 2015). The unprecedented emergence of covid19 onto the social landscape almost revolutionised the HEIs. In 2020, a global pandemic was declared by the World Health Organisation (WHO) due to the spread of COVID-19 virus. Due to COVID-19's highly contagious nature and the ease of spread, most governments adopted proactive measures to contain the virus. These included the declaration of public lockdowns, that included institutions of learning excepting essential services (Zhang, Wang, Yang, \& Wang, 2020; Ezeri, 2020; South African News Agency, 2020). Consequently, for HEIs, learning and teaching became home-based as educators and students worked away from their usual places of engagement. In early April 2020, statistics reported that approximately 1.6 billion, or $91.3 \%$ of learners in 188 countries across all levels of education globally were negatively affected by the compulsory school closure as a result of the lockdowns. The closure of education institutions during this period impacted programme delivery and assessment in HEIs with long and short term consequences.

In the face of the education institutions' closures, the HEIs across the globe re-strategized and redesigned their programme delivery and assessment (UNESCO 2020). The success rate of programme delivery through virtual classroom and laboratory for teaching and learning varies according to countries and institutions (Crawford, et.al., 2020). Some institutions seamlessly transited to distance learning via platforms such as e-learning portals, social medial, school on radio and television programme delivery. However, the majority grappled with virtual teaching and learning with little or no result. The disparities in the success rate of programme delivery during the pandemic hinged upon a number of factors which included, the existing infrastructure in HEIs, location- rural urban dichotomy, students' 
socio-economic background, and the level of instructor's online pedagogical mastery (AAU, 2020; Thakkar \& Joshi, 2018). The sudden virtual teaching approach was greeted with diverse dispositions from different governments across the globe. For instance, in Tunisia, the student union, under the auspices of the General Tunisian Union of Students (UGET), opposed the government's adoption of virtual programme delivery and assessment. The rationale for their opposition was premised on inequality in students' socio-economic background, which deprived the less privileged the opportunity to be part of distance learning (University World News, 2020). Elsewhere, in developed countries such as Finland, a Finish Virtual University was established in early 2000 (Kess, 2003) where students, not only participated in e-learning, but carried out practicals and research in virtual laboratories (Pushpanadham, 2019; Tatli \& Ayas 2013). HEIs in Finland have been operating virtual universities for nearly two decades, which places their HEIs at an advantage when conventional institutions are shut down. The majority of the HEIs in developing nations such as Nigeria, still grapple with blended or mixed programme delivery and assessment, where attention is concentrated on the traditional face-to-face instructional delivery method (Guri-Rosenblit, 2018; Källkvist et.al, 2009) thereby making distance learning in lockdown situations challenging. However, in Nigeria, only a few universities adopted the traditional distance learning method. These include the National Open University of Nigeria (NOUN) designed to accommodate adults who, for various reasons, could not pursue a degree in a conventional university (Ofoha, 2012). The present research investigated how the world HEIs fared vis a vis programme delivery and assessment during COVID-19 occasioned school closures.

\section{Global Agenda on Virtual Programme Delivery and Assessment}

Given the global disparity in internet access and other supporting infrastructure for virtual learning, the United Nations, through UNESCO, is assiduously working towards achieving global virtual programme delivery and assessment. UNESCO (2019), in its Beijing International Conference on Artificial Intelligence and Education report's preamble 11 and 16, states as follows;

\section{Consider also introducing new models for delivering education and training in}

different learning institutions and settings that can be enabled by the use of AI, in order to serve different actors such as students, teaching staff, parents and communities.

16 Apply or develop AI tools to support adaptive learning processes; to leverage the potential of data to enable the evaluation of the multiple dimensions of students' competencies; and to support large-scale and remote assessment.

The feasibility of attaining consistent global programme delivery and assessment in education through technology by year 2030 remains an ongoing challenge depicted in Figure 1 below.

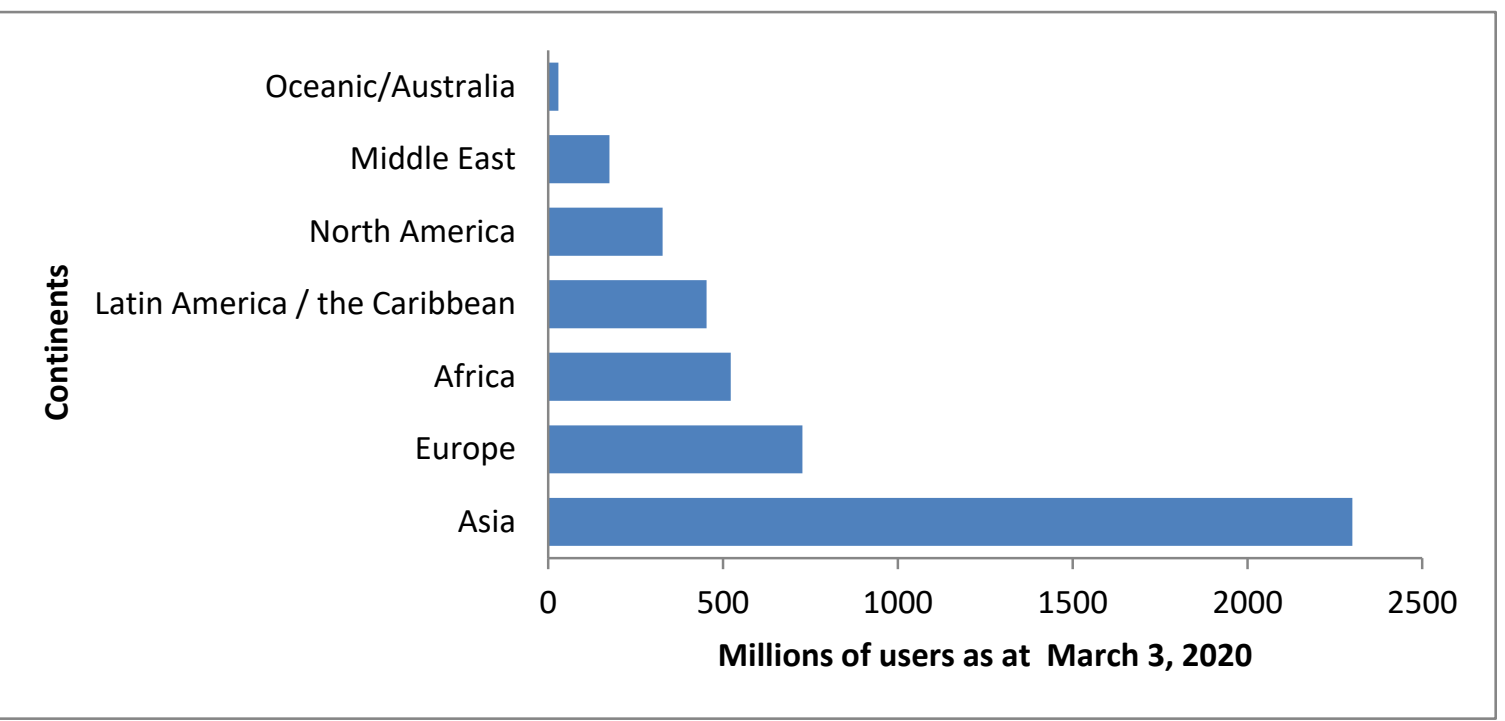

Figure 1. Internet Users in the world by continent - 2020 Q1

Note. Adapted from, Internet World Stats, 2019 Internet Users estimated in ,March 2020. Copyright $\odot$, 2020, Miniwatts Marketing Group 
During the COVID-19 pandemic, the International Association of Universities (2020) embarked on an online survey of the impact of COVID-19 on tertiary institutions worldwide, with a view to understanding the effect on HEIs, specifically the closure of programme delivery and assessment. It was also with a view to finding ways to mitigate these impacts. The access and utilization of internet facilities for the purpose of virtual education is a primary function of national priority and government policy. Figure 1 reflects the extent of the disparity in internet use across the globe (Internet World Starts, 2020).

The World Bank and UNESCO have been clear about the association between internet presence and virtual learning. Data from internetwordstarts.com (2019) differ from those shown in Table 1 below. Notably, is the fact that there is no correlation between a country's internet usage or presence, and the success of virtual programme delivery and assessment. For instance, Nigeria is the sixth country on the list of top 20 countries with the highest number of internet users in the world according to Table 1, yet, the traditional mode of face-to-face programme delivery and assessment is still preferred in the majority of Higher Education Institutions (Nwagwu, 2019).

Table 1. Top 20 Countries with the highest numbers of internet users - 2020 Q1

\begin{tabular}{|c|c|c|c|c|c|c|}
\hline \multirow[t]{2}{*}{$\#$} & \multirow[t]{2}{*}{$\begin{array}{l}\text { Country } \\
\text { Region }\end{array}$} & $\begin{array}{l}\text { Internet } \\
\text { Users }\end{array}$ & $\begin{array}{l}\text { Internet } \\
\text { Users }\end{array}$ & Population, & Population & $\begin{array}{l}\text { Internet } \\
\text { Growth } \\
\text { in } \%\end{array}$ \\
\hline & & 2020 Q1 & $2000 \mathrm{Q} 4$ & 2020 Est. & 2000 Est. & $2000-2020$ \\
\hline 1 & China & $854,000,000$ & $22,500,000$ & $1,439,062,022$ & $1,283,198,970$ & 3796 \\
\hline 2 & India & $560,000,000$ & $5,000,000$ & $1,368,737,513$ & $1,053,050,912$ & 11200 \\
\hline 3 & United States & $313,322,868$ & $95,354,000$ & $331,002,651$ & $281,982,778$ & 328 \\
\hline 4 & Indonesia & $171,260,000$ & $2,000,000$ & $273,523,615$ & $211,540,429$ & 8560 \\
\hline 5 & Brazil & $149,057,635$ & $5,000,000$ & $212,392,717$ & $175,287,587$ & 2980 \\
\hline 6 & Nigeria & $126,078,999$ & 200,000 & $206,139,589$ & $123,486,615$ & 63000 \\
\hline 7 & Japan & $118,626,672$ & $47,080,000$ & $126,854,745$ & $127,533,934$ & 252 \\
\hline 8 & Russia & $116,353,942$ & $3,100,000$ & $145,934,462$ & $146,396,514$ & 3751 \\
\hline 9 & Bangladesh & $94,199,000$ & 100,000 & $164,689,383$ & $131,581,243$ & 94199 \\
\hline 10 & Mexico & $88,000,000$ & $2,712,400$ & $132,328,035$ & $2,712,400$ & 3144 \\
\hline 11 & Germany & $79,127,551$ & $24,000,000$ & $83,783,942$ & $81,487,757$ & 329 \\
\hline 12 & Philippines & $79,000,000$ & $2,000,000$ & $109,581,078$ & $77,991,569$ & 3950 \\
\hline 13 & Turkey & $69,107,183$ & $2,000,000$ & $84,339,067$ & $63,240,121$ & 3455 \\
\hline 14 & Vietnam & $68,541,344$ & 200,000 & $68,541,344$ & 200,000 & 34250 \\
\hline 15 & $\begin{array}{l}\text { United } \\
\text { Kingdom }\end{array}$ & $63,544,106$ & $15,400,000$ & $67,886,011$ & $58,950,848$ & 413 \\
\hline 16 & Iran & $67,602,731$ & 250,000 & $83,992,949$ & $66,131,854$ & 27040 \\
\hline 17 & France & $60,421,689$ & $8,500,000$ & $65,273,511$ & $59,608,201$ & 710 \\
\hline 18 & Thailand & $57,000,000$ & $2,300,000$ & $69,799,978$ & $62,958,021$ & 2478 \\
\hline 19 & Italy & $54,798,299$ & $13,200,000$ & $60,461,826$ & $57,293,721$ & 415 \\
\hline \multirow[t]{4}{*}{20} & Egypt & $49,231,493$ & 450,000 & $102,334,404$ & $69,905,988$ & 10940 \\
\hline & Countries & $3,241,273,512$ & $251,346,400$ & $5,233,377,837$ & $4,312,497,691$ & 1289 \\
\hline & $\begin{array}{l}\text { Rest of the } \\
\text { World }\end{array}$ & $1,332,876,622$ & $109,639,092$ & $2,563,237,873$ & $1,832,509,298$ & 1216 \\
\hline & Total World & $4,574,150,134$ & $360,985,492$ & $7,796,615,710$ & $6,145,006,989$ & 1267 \\
\hline
\end{tabular}

Note. Adapted from, Internet World Stats, 2019 Internet users in top countries Copyright $\odot$ 2019, Miniwatts Marketing Group, www.internetworldstats.com/top20.htm. 
By contrast, Finland did not appear on the list of the global top 20 internet users, despite a consortium of 21 Finnish universities operating virtual education for almost two decades (Kess, 2003). Similarly, South Africa did not feature in the top 20 list, yet the rate of response of South African HEIs towards migration and deployment of online learning platforms during COVID-19 outbreak, was far beyond what was obtainable in Nigeria where, in addition to National Open University of Nigeria (NOUN), only 11 out of 170 universities were authorised to operate dual mode programme delivery and assessment (National University Commission, 2020).

\section{International Disparities in HEIs Responses to Virtual Learning during COVID-19 Pandemic}

Amidst the lock down in various countries, government and HEIs kept devising alternatives to face-to-face programme delivery and assessment. The disparity in nations' responses and the implications on access, quality and equity is a cause for concern. The dichotomy in responses of HEIs in developed and developing nations towards COVID-19 education disruption was quite diverse (UNESCO, 2019). A meta-analysis of this response as shown in Table 2, showed that more than $95 \%$ of 20 countries had declared total HEIs closures. Notably, over $80 \%$ of HEIs in developed nations had switched to virtual/online lecture delivery and assessment.

Table 2. Synthesis and meta-analysis of higher education response by country

\begin{tabular}{|c|c|c|c|}
\hline $\begin{array}{l}\text { WESP } \\
\text { category }\end{array}$ & Country & $\begin{array}{l}\text { Reported campus } \\
\text { closure }\end{array}$ & $\begin{array}{l}\text { Reported move to } \\
\text { online teaching }\end{array}$ \\
\hline \multirow[t]{6}{*}{ Developed Economies } & Australia & All & All \\
\hline & Germany & All & All \\
\hline & Italy & All & All \\
\hline & Republic of Ireland & All & All \\
\hline & United Kingdom & All & All \\
\hline & United State of America & Some & Some \\
\hline \multirow[t]{14}{*}{$\begin{array}{l}\text { Developing } \\
\text { Economies }\end{array}$} & Brazil & Some & Some \\
\hline & China & All & All \\
\hline & Chile & All & Some \\
\hline & Egypt & All & All \\
\hline & Hong Kong & All & All \\
\hline & India & All & Some \\
\hline & Indonesia & All & Some \\
\hline & Jordan & All & Some \\
\hline & Malaysia & All & No \\
\hline & Nigeria & All & Some \\
\hline & Republic of Korea (South Korea) & All & Some \\
\hline & Singapore & Some & Some \\
\hline & South Africa & All & Some \\
\hline & United Arab Emirates & All & Some \\
\hline
\end{tabular}

The situation was opposite in developing economies where, over $80 \%$ of the HEIs partially switched to virtual education while some could not (Crawford, et.al, 2020:21). For instance, All HEIs in Australia, Germany, Italy, Republic of Ireland, United Kingdom and the United State of America had switched to online learning, while in Africa, it was only HEIs in South Africa that had switched to online programme delivery and assessment. In Nigeria, only a few HEIs could transit to partial online learning (Nwagwu, 2019), except National Open University of Nigeria. In Argentina, despite the lockdown, they still made efforts to keep academic activities afloat. For instance, the National 
University of Córdoba conferred degrees on more than 100 graduating students via an online conference - an unprecedented event in the history of the institution. Similarly, in Catholic University of Salta, two graduate students carried out their theses defence via an online platform (Argentina.gob.ar, 2020). The disparity in country responses to programme delivery and assessment amid the COVID-19 occasioned lockdowns, deepens the existing educational lacuna vis a vis access, quality and equity in some of the developing and least developed countries (Mohamedbhai, 2020). It is pertinent to note, that failure to switch to virtual learning in HEIs in developing economies could elongate academic calendar. as it negatively impacts on programme delivery and assessment in HEIs in these countries.

\section{The Oretical Framework}

The study was underpinned by Schein's (1996) extension and elaboration of Lewin's (1947) Organisational Change Theory (OCT), also referred to as "Change as Three Steps" (CATS). Lewin's OCT comprises three steps: i) Unfreeze ii) Change and iii) Freeze. According to Lewin, the "Unfreeze" stage is characterised by "melting" old behaviours and beliefs, resulting in the creation of awareness coupled with a sense of urgency on the need to change the status quo and adopt a new modus operandi among organisation staff members. The "change" stage is where the intended change is effected and the new modus operandi is fully introduced and the status quo abandoned. The last stage is where the change has been formed and reinforced. Several change theories and models have been developed (Mayne, 2015; Serrat, 2017), yet, their underlying principles and assumptions are traceable back to Lewin's OTC (Esa, Muda, Ibrahim \& Mansor, 2017).

\subsection{Change Theory as a Framework for Deployment of Virtual Learning in HEIs}

Going by various national government directives to their education institutions to sustain teaching and learning amidst HEIs closures occasioned by the COVID-19 pandemic (Zhang, Wang, Yang, \& Wang, 2020), HEIs administrators were left with no option but to adopt a virtual education model. During the pandemic, institutions in developed countries that were previously practicing blended programme delivery and assessment could transit seamlessly to e-learning, while the process appeared to be overwhelming or practically impossible for other institutions in developing countries due to their overdependence on face-to-face teaching and learning approach. This lacuna could be bridged through the application of Lewin's (1947) OTC as discussed below.

At the Motivation for Change (Freezing) Stage, HEIs administrators (change managers) are expected to motivate staff members and students who would be the most concerned. The three stages (disconfirmation, induction of guilt/survival anxiety and learning anxiety) that characterised this phase of change were observed to be obtainable in HEIs. For instance, staff members and students are likely to put up a defence (Mukeredzi, 2020), hence the change manager should motivate and sensitise teaching and support staff and students on the necessity for the adoption of an alternative or complementary mode of learning. Induction of guilt/survival anxiety could be achieved among members of staff by calling their attention to the possibility of being left behind in terms of prevailing global best practices and losing their jobs. Students could also be made to realise the cost and time implications of an elongated academic calendar. Here, the administrators should juxtapose the benefit of the proposed change with that of the status quo. To mitigate Learning Anxiety, which could manifest in form of technology phobia and fear of workers losing their jobs, as well as students fear of failure, a safety net should be presented in form of test running virtual learning for a given period to accommodate trial and error.

At the Imitation and positive or defensive identification with role model (Change) phase, change managers must ensure that learners (members of staff and students) are adequately integrated into virtual learning via cognitive restructuring. Notably, change managers at this stage could be experts from the institution's Information Communication Telecommunication (ICT) Unit or a consultant. A conducive environment is vital in this process; hence, the change agent must ensure that necessary provisions are in place to achieve the desired change. In this case, necessary infrastructures in form of computer laboratory, internet facilities, and regular power supply should be ascertained. Moreso, efforts should be made to ensure that members of staff and students possess required gadgets such as internet-enabled laptop computers and mobile devices that are compatible with the platforms through which online programme delivery and assessment will be deployed. Finally, Personal and Relational (Refreezing) Stage, presents the opportunity to reinforce the new culture of virtual learning in learners. Change managers must ensure that learners personal and organisational culture reflects the change- the adoption and use of virtual learning as a means of programme delivery and assessment in HEIs.

\subsection{Research Questions}

1. What are the challenges surrounding HEIs' transition to virtual programme delivery and assessment during the COVID-19 outbreak? 
2. What are the possible strategies to mitigate these challenges in future?

\section{Method of Data Collection and Sampling Technique}

This study adopted a simple qualitative research design, and data were collected through a "free attitude interview" (Meulenberg-Buskens, 1997), which affords the participants the opportunity to express their views and experiences vis-a-vis the problems and possible solutions as indicated in the research questions. Ten participants were selected across the globe (cutting across developed, developing and least developed countries)-using convenience sampling technique. The rationale for the choice of convenience, otherwise known as 'accidental sampling', technique was premised on the on-going "lockdown" directive that prevented movement at the time of this study. The sampling technique was also appropriate at the time when it was almost impossible to have face-to-face contact with participants (Dörnyei, 2007). Participants were selected and interviewed via global online academic research community/platforms, Whatsapp, and email. Participants were drawn from four continents - two developed continents of Europe and Asia, and two developing continents of North America and Africa. Participants comprised of faculties with minimum of three years of experience in teaching and research in HEIs. Among the participants were head of institute of education development and lecturers who specialised in higher education as their area of research interest.

\subsection{Data Analysis and Ethical Considerations}

The data were analysed using Thematic Analysis (TA) (Braun \& Clarke, 2006), which is "a method of identifying, analysing, and reporting patterns or (themes) within the data. The six-steps of TA were adopted by grouping participants' responses in relation to the phenomenon under study into themes for analysis. Ethical considerations were observed whereby participants were allowed to respond freely to the issues raised and were equally allowed to withdraw from the study should need arise. As a measure to protect the participants' privacy and confidentiality, codes P1 through P10 were used.

\subsection{Data Presentation and Discussion of Findings}

In response to the research questions, data were presented in a manner consistent with the questions raised in the study. The questions were as follows; question one focused on eliciting information on the challenges confronting HEIs in their bid to transit to virtual learning as occasioned by COVID-19 induced lockdowns. Emerging from participants' responses were two major views namely; (a) proficiency in virtual pedagogy among lecturers, and students' phobia for virtual learning, and (b) the digital divide challenge among students and nations. Question two was also raised to explore possible strategies to mitigate these challenges in the future. Two major views also evolved from participants' responses as strategies for mitigating such challenges in the future. These included (a) the inevitability of lecturers' and students' training and re-training and (b) provision of virtual learning enabling infrastructures.

\section{Proficiency in Virtual Pedagogy among Lecturers and Students Phobia of Virtual Learning}

\subsection{Proficiency in Virtual Pedagogy among Lecturers}

There exists consensus among scholars that virtual programme delivery and assessment requires a new set of pedagogical skills (Adnan, 2018 \& Ní Shé., Farrell, Brunton, Costello, Donlon, Trevaskis and Eccles, 2019) yet, students; by virtue of being accustomed to, and the prevalence of face-to-face method of programme delivery and assessment, often display apprehension towards virtual learning. The above assertions are in tandem with the views of the participants as analysed below.

\section{$\mathbf{L} 2$... in developing countries, ... teachers are not trained for that purpose ...}

\section{L3 Virtually all countries and all levels of education are not finding it interesting to respond} to the lacuna of COVID-19 when it comes to a complete switch from the mixed-method (contact and Virtual session) they are used to and the virtual teaching-learning method.

\section{L5: lecturers at the developing nations find it hard to transform from classroom setting to} virtual learning.

The observation and submission of L2 reveals that COVID-19 outbreak coerced lecturers into the adoption of virtual programme delivery and assessment; hence, many lecturers in developing countries lacked the requisite virtual pedagogical skills for programme delivery and assessment. L5 statement shows that lecturers from developing countries lag behind in transitioning to online programme delivery and assessment during the lockdown. L3's view 
observes the challenges of adaptability faced by both lecturers and students in a bid to switch to virtual learning. It can be deduced from the participants' responses that lecturers' over-reliance on face-to-face teaching made it difficult to switch to online programme delivery and assessment during the COVID-19 lockdown. This is in consonance with the findings of Saadé, Kira, Mak, \& Nebebe (2017) that, students do experience some sort of anxiety with online courses.

\subsection{Student Phobia for Virtual Learning}

Apart from the lecturers' lack of requisite skills, apprehension/anxiety was expressed by students as negative impacts upon the success rate and effectiveness of virtual learning in developing countries. Participants stated the following:

L4 ...students in HEIs in developing countries are always negative and full of fear of the unknown.

L8 In my country, Iraq, students did not get used to electronic education. They used to have a class and teacher explaining the matter to them directly...

L4's statement depicts that the disposition of students in developing countries towards online learning was negative, and stemmed from their anxiety over what would become of their academic outcome/performance. It could be inferred that students in HEIs in developing countries were unfavourably disposed to virtual learning owing to the unfounded fear of failure. This view was also reinforced by L8's statement, that students were not familiar with online learning, which further explains the reason for their virtual learning phobia. This concurs with Pushpanadham's (2019) idea that learners' readiness is a key factor in determining the success of digital/virtual education. Students were apprehensive about the possible negative implication of virtual education on their learning outcomes. Cabi \& Kalelioglu (2019) reported that student attitudes towards virtual learning was positive for the majority, while the minority were unfavourably disposed.

\subsection{The Challenge of Digital Divide among Students and Nations}

The success of virtual learning, to a great extent, relied on computer availability and proficiency of both instructors and the learners. This was also confirmed by the responses of the participants as follows:

L2 ...limitations of the student body with the possession of a computer, mobile or tablet. Similarly, access to the internet, for various reasons (financial, connection, etc.) is a major limitation.

L3 A significant percentage of students live in rural areas with little or no access to the internet. Not only that, some students are from the previously disadvantaged socio-economic backgrounds with little of or no economic buoyancy to possess computer sets and other needed sophisticated tools to meet up with virtual teaching and learning.

L5 Students' attitude in developed nations easily adapts to virtual learning

L4 Students' and lecturers in the developed countries have little or no problem adopting the virtual learning as it had been part of their learning process before COVID 19

L7 ...the data issue. The setup of environment all make it challenging.

L2 shared the view that not all students could afford gadgets and access to internet in their respective homes. This also reflected in L3 statement, that students from low socio-economic background are confronted with a myriad of challenges such as lack of internet-enabled devices, poor or no availability of internet service which are basic requirement for virtual learning. On the area of digital divide among nations, L5 shared the view that students in developed nations found it easy to switch to online learning than their counterparts in some developing nations. 
According to L4, he easy of switch was as a result of the mixed method of programme delivery and assessment adopted by many of the institutions in the developed countries. This view was also supported by 27 who claimed that environmental setup made the difference in HEIs responses to switch to virtual learning. The data revealed that a digital divide existed among students and nations. Some students could not participate in virtual programme delivery and assessments due to lack of requisite IT gadgets such as laptops, tablets and internet access. It was also discovered that there existed a dichotomy in the rate at which developed and developing nations embraced virtual learning, attributable to national development that gives room for virtual learning (Crawford, et.al, 2020:21).

\subsection{Possible Strategies to Mitigate Deficiencies in Transition to Virtual Learning in Future}

In a bid to forestall the adoption of virtual learning in HEIs around the globe, solutions were proffered by participants under two broad headings; (a) inevitability of training and re-training for lecturers and students, and (b) provision of virtual learning enabling infrastructure.

\subsection{Inevitability of Training and Re-Training}

Training and re-training has been established as a key factor in determining how receptive organisational staff would be to change (Esa, Muda, Ibrahim, and Mansor, 2017). Participants' opinions were sought on possible strategies to forestall the reoccurrence of the prevailing malady of lack of competence among lectures and students. Their responses were as follows;

L4: In areas where itches or problems are encountered, the management of the learning institutions should try as much as possible to organise training sessions on the virtual learning processes for the students and lecturers.

L2: The need to create new educational models implies establishing the pedagogical principles that guide it.

L3: I, therefore, think that institutions must at all-time, ensure that students and staffs, most especially lecturer, is used to the virtual teaching-learning system even after COVID-19. This will enable them to respond without creating any vacuum should the case or similar contingency happens in the future.

L8: ... students do not accept education online due to the psychological factor to accept the idea of education electronically. They need time until they get used to it.

L9: ...because it is considered as new idea and this idea doesn't correspond with student culture within developing countries (including Iraq) and require long time and huge resources to applied in right way".

Based on the response by L4, school management should embark on intensive training for lecturers and students on the use of online platforms for virtual learning. L2 reiterated the need for lecturers to acquire virtual programmes delivery and assessment pedagogy via training. There exists a point of intercession among L3, L8 and L9 views on the need for a considerable length of time for students and lecturers to get accustomed to virtual learning. Given the fact the online education is alien to some lecturers and students, especially in developing and least developed countries, proper integration of virtual learning would require time.

The data collected revealed that training and retraining of staff and students, coupled with ample time for the purpose of acclimatisation, may equip HEIs to confront emergency school closures, (as occasioned by COVID-19 pandemic; in the future. This confirms the view of Rhema and Miliszewska (2014) that, the provision of appropriate training in 
higher education institutions for (students and lecturers) through online learning platforms is germane to the success of virtual learning. Similarly, the imperative of virtual education pedagogy for online instructors was also ascertained by Sun and Chen (2016). Brinkerhoff \& Koroghlanian, (2005:27) reported that the "results indicated that within a four-year time frame, student skills and attitudes remained relatively stable with some positive shifts." Hence, institution management teams should be willing to invest appreciable efforts and time on training and retraining all staff members and students.

\subsection{Provision of Virtual Learning Enabling Infrastructures}

The indispensability of a virtual learning environment as a framework for the efficient deployment of online education, was also identified by the participants as a key factor.

L1: To a large extent, the possibilities of choosing specific educational and pedagogical methods are determined.... by specific ICT and Internet information technology instruments, implemented Industry 4.0 technologies, remote communication applications, online educational platforms, technical capabilities of computer equipment, technical parameters of Internet bandwidth, laptops, smartphones, etc. that are available to students and teachers.

L5: ... provision of learning materials in terms of laptop computers to students and lecturers especially students from rural background.

According to L1, the model and adoption of e-learning and appropriate pedagogies was a function of the availability of arrays of infrastructural facilities. These include the type of online educational platforms, the capabilities of both desktop and laptop computers, availability of smartphones, and the internet bandwidth. It can be inferred from these statements that despite availability of infrastructural facilities, their configurations deserve closer attention as the capacities of the devices and bandwidth required for virtual learning should be of high standard. For instance, some e-learning platforms are multimedia and require high bandwidths such as the $3 \mathrm{G}$ and $4 \mathrm{G}$ network, as accessing such platforms with $2 \mathrm{G}$ network would not yield the desired results. L5 also reinforced the need to ensure that lecturers and students have access to devices such as smartphones, tablets, laptops and desktop computers. The provision of virtual learning enabling infrastructural facilities/environment would go a long way in mitigating the challenges surrounding HEIs migration to virtual learning. This is consistent with Thakkar and Joshi's (2018) and Pushpanadham's (2019) idea that the success of virtual learning is a function of availability of internet-enabled devices, as well as high broad broadband internet service.

\section{Conclusion and Recommendations}

It is a reality that all higher education institutions across the globe have been forced to close in response to COVID-19 pandemic, prompting HEIs to transit to a virtual learning platform. This study examined the virtual programme delivery assessment in HEI's around the world during COVID-19 pandemic. The findings revealed that: lecturers, especially those in developing countries, lacked the requisite technical know-how and proficiency for virtual programme delivery and assessment; and students anxiety levels over HEIs adoption of virtual learning and the digital divide among students and developing nations, were a cog in the wheel of virtual programme delivery and assessment during the pandemic. Training and re-training of lecturers and students, and the provision of virtual learning enabling infrastructure, were recommended to mitigate the lapses associated with HEIs transition to virtual learning in emergency situations as occasioned by COVID-19 pandemic in the future. From the theoretical perspective, the principles of Lewin's (1947) OTC served as framework for a successful transition from face-to-face teaching-learning methods to virtual learning programme delivery and assessment in HEI's globally. 


\section{References}

AAU. (2020). The AAU and the RRENs Call for strengthening of campus network infrastructure for African Higher Education Institutions to cope with COVID-19 disruptions. Retrieved from https://ubuntunet.net/2020/04/the-aau-and-the-rrens-call-for-strengthening-of-campus-network-infrastructure-fo r-african-higher-education-institutions-to-cope-with-covid-19-disruptions/

Adedayo, S. (2015). Education and Politics: Its Implications for National Transformation in Nigeria. Public Policy and Administration Research, 5(8), 40-45. http://doi=10.1.1.820.4832\&rep=rep1\&type=pdf

Adnan, Müge. (2018). Professional development in the transition to online teaching: The Voice of Entrant Online Instructors, ReCALL, 30(1), 88-111. https://doi.org/10.1017/S0958344017000106

Argentina.gob.ar (2020) Universities in Coronavirus time: virtual classes and streaming collations Retrieved from. https://www.argentina.gob.ar/noticias/universidades-en-tiempo-de-coronavirus-clases-virtuales-y-colaciones-po r-streaming

Braun, V. \& Clarke, V. (2006). Using thematic analysis in psychology. Qualitative research in psychology, 3(2), 77-101. https://doi.org/10.1191/1478088706qp063oa

Brinkerhoff, J. \& Koroghlanian, C. M. (2005). Student computer skills and attitudes toward internet-delivered instruction: An assessment of stability over time and place. Journal of Educational Computing Research, 32(1), 27-56. https://doi.org/10.2190/AR4T-V3P8-UMMX-AB4L

Cabi, E. \& Kalelioglu, F. (2019). A fully online course experience from students' perspective: readiness, attitudes and thoughts. Turkish Online Journal of Distance Education, 20(3), 165-180. https://doi.org/10.17718/tojde.601934

Crawford, J., Butler-Henderson, K., Rudolph, J., Malkawi, B., Glowatz, M., Burton, R. \& Lam, S. (2020). COVID-19: 20 Countries' higher education intra-period digital Pedagogy Responses. Journal of Applied Learning and Teaching. 3(1), 1-40. https://doi.org/10.37074/jalt.2020.3.1.7

Cummings, S., Bridgman, T. \& Brown, K. G. (2016). Unfreezing change as three steps: Rethinking Kurt Lewin's legacy for change management. Human Relations, 69(1), 33-60. https://doi.org/10.1177/0018726715577707

Dörnyei, Z. (2007). Research methods in applied linguistics. Oxford University Press. New York. Retrieved April 25, 2020

from https://https://www.scirp.org/(S(vtj3fa45qm1ean45vvffcz55))/reference/ReferencesPapers.aspx?ReferenceID=2 083915

Erezi, D. (2020). NUC orders closure of all universities nationwide. The Guardian. Retrieved March 22, 2020. URL: https://guardian.ng/news/nuc-orders-closure-of-all-universities-nationwide

Esa, N., A., Muda, M.S.B., Ibrahim, M.Y.B. \& Mansor, N.R.B. (2017). The application of Kurt Lewin's model of change in the implementation of higher order thinking skills in school. International Journal of Academic Research in Business and Social Sciences, 7(8), 109-115. https://doi.org/10.6007/IJARBSS/v7-i8/3212

Francois E.J. (2015). Education and Society. In: Building Global Education with a Local Perspective. Palgrave Macmillan, New York. https://doi.org/10.1057/9781137386779_1

Gary A. Dworkin et al., (2013), The sociology of education, Sociopedia.isa, https://doi.org/10.1177/2056846013122

Guri-Rosenblit, S. (2018). E-Teaching in Higher Education: An essential prerequisite for e-Learning. Journal New Approaches in Educational Research, 7(2), 93-97. https://doi.org/10.7821/naer.2018.7.298

International Association of Universities. (2020). Impact of COVID-19 on Higher Education. Retrieved April 12, 2020 from https://www.iau-aiu.net/IMG/pdf/iau_survey_covid-19.pdf

Internetworldstats. (2020). Internet Users in the world by geographical regions - 2020 Q1 Retrieved May 12, 2020 from https://www.internetworldstats.com/stats.htm https://doi.org/10.1016/S1365-6937(20)30113-1

Internetworldstats. (2020). Top 20 Countries with the highest numbers of internet users - 2020 Q1. Retrieved May 12, 2020 from https://www.internetworldstats.com/top20.htm

Jensen, T. (2019). Higher education in the digital era: The current state of transformation around the world in the digital era. International Association of Universities. Retrieved April 16, 2020 from https://iau-aiu.net/IMG/pdf/technology_report_2019.pdf 
Källkvist, M., Gomez, S., Andersson, H. \& Lush, D. (2009). Personalized virtual learning spaces to support undergraduates in producing research reports: Two case studies. Internet and Higher Education, 12(1), 35-44. https://doi.org/10.1016/j.iheduc.2008.10.004

Kess, P. (2003). The Finnish virtual university. IFAC Proceedings, 36(10), 23-28. https://doi.org/10.1016/S1474-6670(17)33648-0

Mark, T. \& Sar, D. (2015). The concepts of politics, education and the relationship between politics and education in Nigeria. Danish Journal of Sociology and Political Sciences, 15-18.

Mayne, J. (2015). Useful theory of change models. Canadian Journal of Program Evaluation, 30.2(Fall/autumn), 119-142. https://doi.org/10.3138/cjpe.230

Meulenberg-Buskens, I. (1997). The Free Attitude Interview. Unpublished Notes

Mohamedbhai, G. (2020). COVID-19: What consequences for higher education? University World News, Africa $\begin{array}{lllll}\text { Edition. } & \text { Retrieved } & \text { May } & 5, & 2020\end{array}$ https://www.universityworldnews.com/post.php?story=20200407064850279

Mukeredzi T. (2020) Students reject online learning as data costs hiked by 225\%. University World News. Retrieved May 5, 2020 from https://www.universityworldnews.com/post.php?story=20200504142003239

National University Commission (2020). The list of approved Distance Learning Centers. https://www.nuc.edu.ng/distance-learning-centers

Ní Shé, C., Farrell, O., Brunton, J., Costello, E., Donlon, E., Trevaskis, S., \& Eccles, S. (2019) Teaching online is different: critical perspectives from the literature. Dublin: Dublin City University. https://doi.org/10.5281/zenodo.3479402

Nwagwu, W.E. (2019). E-learning readiness of universities in Nigeria- what are the opinions of the academic staff of Nigeria's premier university? Education and Information Technologies 25: 1343-1370. https://doi.org/10.1007/s10639-019-10026-0

Ofoha, D. (2012). Contribution of Open and Distance Learning Programmes to Human Capacity Development: The Case of the Primary Education Programme of the National Open University of Nigeria. Makerere Journal of Higher Education, 3(2), 123-139. https://doi.org/10.4314/majohe.v3i2.10

Pushpanadham, K. (2019). Massive Open Online Courses: The emerging landscape of digital learning in India. International Institute for Educational Planning. Paris, France. www.iiep.unesco.org

Rhema, A. \& Miliszewska, I. (2014). Analysis of student attitudes towards e-learning: The case of engineering students in Libya. Issues in Informing Science and Information Technology. 11, 169-190. https://doi.org/10.28945/1987

Saadé, R. G., Kira, D., Mak, T., \& Nebebe, F. (2017). Anxiety and Performance in Online Learning. Proceedings of the Informing Science and Information Technology Education Conference, Vietnam, 147-157. Santa Rosa, CA: Informing Science Institute. Retrieved May 10, from http://www.informingscience.org/Publications/3736

Serrat O. (2017). Theories of Change. In: Knowledge Solutions. Springer, Singapore. https://doi.org/10.1007/978-981-10-0983-9_24

South African News Agency. (2020) Coronavirus 101. Retrieved March 22, 2020, https://www.sanews.gov.za/south-africa/coronavirus-101

Sun, A., \& Chen, X. (2016). Online education and its effective practice: A Research Review. Journal of Information Technology Education, 15, 157-190. https://doi.org/10.28945/3502

Tatli, Z. \& Ayas, A. (2013) Effect of a virtual chemistry laboratory on students' achievement. Educational Technology \& Society, 16(1), 159-170. Retrieved March 2020. https://www.jstor.org/stable/jeductechsoci.16.1.159?seq=1\#metadata_info_tab_contents

Thakkar, S. R \& Joshi, H. D. (2018). Impact of technology availability and self-efficacy on e-learning usage. International Journal for Research in Applied Science \& Engineering Technology, 6(4), 2956-2960. https://doi.org/10.22214/ijraset.2018.4492

UNESCO, (2019). Beijing consensus on artificial intelligence and education. UNESCO International Conference on Artificial Intelligence and Education, France. https://unesdoc.unesco.org/ark:/48223/pf0000368303 
University World News (2020). Union opposes online classes as 'violation of equality' Retrieved May 5, 2020, from https://www.universityworldnews.com/post.php?story=20200325083138992

World Bank. (2018). World Development Report 2018: Learning to Realize Education's Promise, Technical report, The World Bank, Washington, DC.

World Health Organisation. (2020). Coronavirus disease 2019 (COVID-19) Situation Report - 46. Data as reported by national authorities by $\mathrm{T} 06$ March 2020. Retrieved May 1, 2020, from https://www.who.int/docs/default-source/coronaviruse/situation-reports/20200306-sitrep-46-covid-19.pdf?sfvrs $\mathrm{n}=96 \mathrm{~b} 04 \mathrm{adf} \_4$

Zhang, W., Wang, Y., Yang, L. \& Wang, C. (2020). Suspending classes without stopping learning: China's education emergency management policy in the COVID-19 outbreak. Journal of Risk and Financial Management, 13(3), 55. https://doi.org/10.3390/jrfm13030055 